\title{
Safety profile of the new 5-ASA based compounds
}

\author{
VINOD K SHARMA, MD, FRCPC
}

ABSTRACT: 5 -aminosalicylic acid (5-ASA) preparations were anticipated to be and generally are better tolerated than sulphasalazine. Minor side effects such as headache, dizziness, abdominal pain and nausea do occur but are not more frequent than in placebo-treated patients. Approximately $10 \%$ of patients thought to be allergic to sulphasalazine are also allergic to 5-ASA. An idiosyncratic reaction with worsening of symptoms can occur. Diarrhea is more common with olsalazine, and it is due to the effect of olsalazine itself on the small bowel, not the 5-ASA component. There are case reports of pancreatitis, pericarditis and bronchospasm, retrosternal chest pain, mild neutropenia, nephrotic syndrome and hair loss associated with 5.ASA treatment. Patients with oligospermia due to sulphasalazine have improved when switched to 5 . ASA. 5-ASA enemas can cause local irritation or other effects resulting from enema tip insertion. Can J Gastroenterol 1990;4(7):443-445

\section{Key Words: 5-ASA, Adverse effects, Safety}

\section{Le profil d'innocuité de l'acide 5-aminosalicylique et des nouveaux analogues salicylés}

RESUME: Ainsi qu'on l'avait supposé, les préparations à base d'acide 5 . aminosalicylique sont généralement mieux tolérées que la sulfasalazine. Les effets secondaires mineurs tels que céphalés, étourdissements, douleurs abdominales et nausées surviennent mais ne sont pas plus fréquents qu'avec le placebo. Près de $10 \%$ des patients qui semblent allergiques à la sulfasalazine le sont également au 5-ASA. Une réaction idiosyncrasique et l'aggravation des symptômes peuvent survenir. La diarrhée est plus fréquente qu'avec l'olsalazine; elle est attribuable à l'effet de l'olsalazine sur le grêle et non pas à l'élément 5-ASA. Pancréatite, péricardite, bronchospasme, douleurs thoraciques rétrosternales, neutropénie peu sévère, syndrome néphrotique et alopécie accompagnent parfois le traitement par 5-ASA. Les patients atteints d'une oligospermie due à la sulfasalazine s'améliorent quand ils passent au 5-ASA. Les lavements à base de 5-ASA peuvent causer une irritation locale ou d'autres effets résultant de l'insertion de la canule rectale.

$S^{\mathrm{s}}$ LPHASALAZINE WAS CREATED IN the 1930 s by Svartz for the treatment of rheumatoid arthritis. It was by chance that favorable effects were noted in ulcerative colitis (1). In the early 1950s sulphasalazine was used in the United States for the treatment of ulcerative colitis with good results. It became available in Great Britain in 1955. Since then it has been shown in controlled trials to be effective in the treatment of acute ulcerative colitis $(2,3)$ as well as in maintenance therapy (4-6). However, sulphasalazine did not completely eliminate the risk of recurrent attacks and a proportion of patients could not tolerate sulphasalazine in therapeutic doses (7). Most of the side effects of sulphasalazine have been ascribed to the sulfapyridine moiety and correlate well with sulfapyridine serum levels (8).

Sulphasalazine has an unusual metabolism. Only 20 to $30 \%$ of the orally administered dose is absorbed from the upper gastrointestinal tract (9). A major part of the absorbed sulphasalazine is excreted in the bile without modification by the liver and undergoes enterohepatic circulation (9). Less than $10 \%$ is excreted unchanged in urine.

About $75 \%$ of sulphasalazine reaches the colon unchanged, where the azobond is split by the bacterial azo-reductase enzyme into the metabolites 5.ASA and sulfapyridine. Most of the sulfapyridine is absorbed and acetylated, hydroxylated and conjugated with glucuronides for excretion in urine $(10,11)$. The majority of 5-ASA remains within the colon and can be recovered in the feces. A small part is absorbed and acetylated by the colonic epithelium, liver and kidney, and excreted in urine. When 5-ASA and sulfapyridine are administered as single agents orally, each is promptly absorbed in the proximal gastrointestinal tract, metabolized by the liver and excreted in urine $(10,12)$. 
In 1977 it was demonstrated that 5-ASA is the active moiety of sulphasalazine for the treatment of ulcerative colitis (13). This has since been confirmed (14), and led to the development of two types of agents: compounds in which sulfapyridine is replaced by another carrier molecule, considered to be less likely to produce side effects. (One ingenious structure is olsalazine, where two molecules of 5-ASA are joined by an azobond. These compounds require bacterial enzyme action to be split into the active compounds in the distal ileum and colon); and 5-ASA (mesalamine) with various coating systems to retard upper gastrointestinal absorption and thus minimize possible renal toxicity.

It appears reasonable to assume that the spectrum of untoward effects is similar for the various mesalamine products and that the side effects caused by a new azo-compound of 5 . ASA could differ in certain respects from mesalamine formations.

\section{MESALAMINE}

Because sulphasalazine was already in clinical use with most of the side effects thought to be related to the sulfapyridine moiety, 5-ASA, the active moiety, was anticipated to be safer to use and its introduction to clinical medicine followed a somewhat different sequence.

Initial animal experiments using 5 . ASA by Calder et al (15) on rats showed nephrotoxicity. Single intravenous injection of 5-ASA at dosages of $1.4,2.8$ and $5.7 \mathrm{mM} / \mathrm{kg}$ caused renal cortical necrosis in 23 of 60 rats, 13 of which also had associated papillary necrosis. Higher dosages tended to produce more severe lesions but there were exceptions. As 5-ASA has molecular similarities to phenacetin, the sporadic and incomplete incidence of renal lesions was thought to be due to a similar mechanism seen with analgesics .

An open study of 5-ASA (Pentasa; Nordic Laboratories) was performed by Rasmussen et al (16) in 18 patients with Crohn's disease unresponsive to other drugs. Oral Pentasa, $500 \mathrm{mg}$ tid, was effective and was not associated with any side effects. In particular, there was no change in the urinary sediment or ${ }^{51} \mathrm{Cr}$ EDTA plasma clearance. None of the other biochemical and hematological tests showed any alteration.

Since then there has been only one report of a patient who developed nephrotic syndrome after five months of treatment with mesalamine $800 \mathrm{mg}$ tid (17). In the study by Riley et al (18) two of 21 patients treated with Asacol (Norwich-Eaton) $1200 \mathrm{mg}$ twice daily for four weeks developed up to a twofold rise in plasma creatinine which returned to normal after discontinuation of treatment. One further patient has been reported to have a decrease in creatinine clearance on Asacol treatment (19). This patient had previously been treated with sulphasalazine without difficulty. In the post marketing adverse reaction reporting of various Salofalk (Interfalk) preparations between 1984 and 1989, using 663,608 patients/treatment cycle, only six cases of interstitial nephritis were noted (personal communication)

Mesalamine was initially used in patients allergic or intolerant to sulphasalazine (19-26). Approximately $85 \%$ of these patients were able to tolerate mesalamine. It appears that patients who experienced allergic and upper gastrointestinal effects while receiving sulphasalazine commonly experience a similar reaction to mesalamine $(20,21,23,25)$. Leukopenia has been reported on substitution of mesalamine for sulphasalazine in a patient who had developed leukopenia while being treated with sulphasalazine (25). In a randomized trial the incidence of headache was reported to occur with similar frequency during treatment with mesalamine or sulphasalazine (27). Riley et al (28) noted that headache resolved during continued therapy more often in patients treated with mesalamine $(80 \%)$ than in those receiving sulphasalazine $(50 \%)$ and that regular headaches were more common with sulphasalazine $(\mathrm{P}<0.02)$. Donald et al (22) noted that two patients who were receiving Asacol $1600 \mathrm{mg} /$ day and experiencing headaches were free from headaches at a reduced dose of $800 \mathrm{mg} /$ day. This sug- gests that not all of the allergic side effects or intolerance to sulphasalazine are related to the sulfapyridine component. In a recent international ran. domized double-blind study comparing sulphasalazine and mesalamine the incidence of headache and epigastric pain was similar in the two groups, and the incidence of hypersensitivity reac. tions and nausea and vomiting was four times more in the sulphasalazine group compared to the mesalamine group (29).

In a placebo controlled randomized study of oral 5-ASA, there was no sig. nificant difference in the incidence of adverse symptoms compared to the placebo group (30). Other unpublished studies have noted similar findings. Occasionally pancreatitis can occur $(29,31,32)$. Case studies of pericarditis (33), myocarditis (34) and hair loss (35) have been reported.

In the National Cooperative Crohn's Disease Study (36), apart from the occurrence of loose stools or overt diarrhea, the reported adverse events were not more common in the sul. phasalazine group than in the placebo group.

The cause of olsalazine-induced diarrhea is not known. Studies in patients with permanent ileostomies have shown that olsalazine dose-dependently increases ileostomy output (37). This is not mediated by prosta. glandin $\mathrm{E}_{2}$ or $\mathrm{F}_{2}$. Experiments in rats have shown that olsalazine can inhibit small intestinal transport systems and that, at high concentrations, it can induce chloride and water secretion $(38,39)$. In a clinical study, diarrhea during olsalazine therapy occurred more often in patients with pancolitis than in those with distal ulcerative colitis (40).

\section{CONCLUSIONS}

The new 5-ASA agents are general. ly well tolerated. Overall 80 to $90 \%$ of patients intolerant to sulphasalazine can tolerate the new 5-ASAs. Ten to $20 \%$ have a similar allergic reaction to the new agents as to sulphasalazine. Diarrhea due to olsalazine is dose-related and may be due to its effect on the small intestine. The new agents are 
capable of delivering the active agent to the small bowel in Crohn's disease, but there is a possibility that absorption may lead to nephrotoxicity with higher doses given over prolonged periods.

\section{REFERENCES}

1. Svartz N. Salazopyrin, a new sulfanilamide preparation. Acta Med Scand 1942;110:577-98

2. Baron JH, Connell AM, LennardJones JE, et al. Sulphasalazine and salicylazosulphadimidine in ulcerative colitis. Lancet 1962;i:1094-6.

3. Dick AP, Grayson MJ, Carpenter RG, et al. Controlled trial of sulphasalazine in the treatment of ulcerative colitis. Gut 1964;5:437-42.

4. Misiewiecz JJ, Lennard-Jones JE, Connell AM, et al. Controlled trial of sulphasalazine in the maintenance therapy for ulcerative colitis. Lancet 1965;i:185-8.

5. Dissanayake AS, Truelove SC. A controlled therapeutic trial of long term maintenance treatment of ulcerative colitis with sulphasalazine (Salazopyrin). Gut 1973;14:923-6.

6. Azad Khan AK, Howes DT, Piris J, et al. Optimum dose of sulphasalazine for maintenance treatment in ulcerative colitis. Gut 1980;21:232-40.

7. Das KM, Dubin R. Clinical pharmacokinetics of sulphasalazine. Clin Pharmacokinet 1976;1:406-25.

8. Das KM, Eastwood MA, McManus JPA, et al. Adverse reactions during salicylazosulfapyridine therapy and the relation with drug metabolism and acetylator phenotype. N Engl J Med 1973:73:520-4.

9. Das KM, Choudhury JR, Zapp B, et al. Small bowel absorption of sulfasalazine and its hepatic metabolism in human beings, cats and rats. Gastroenterology 1979;77:280-4.

10. Schroder H, Campbell DE. Absorption, metabolism, and excretion of salicylazosulfapyridine in man. Clin Pharmacol Ther 1982;13:539-51.

11. Das KM, Eastwood MA, McManus JPA, et al. The metabolism of salicylazosulfapyridine in ulcerative colitis. Gut 1973;14:631-6.

12. Shafii A, Choudhury JR, Das KM. Absorption, enterohepatic circulation and excretion of 5-aminosalicylic acid in rats. Am J Gastroenterol 1982;77:297-9.

13. Azad Khan AK, Piris J, Truelove SC. An experiment to determine the active therapeutic moiety of sulphasalazine. Lancet 1977;ii:892-5.

14. Van Hees PAM, Bakker JH, Van Tongeren JHM. Effect of sulpha- pyridine, 5-aminosalicylic acid, and placebo in patients with idiopathic proctitis: A study to determine the active therapeutic moiety of sulphasalazine. Gut 1980;21:632-5.

15. Calder IC, Funder CC, Green CR, Harn KN, Tange JD. Nephrotoxic lesions from 5-aminosalicylic acid. Br Med ] 1972;1:152-4.

16. Rasmussen SN, Binder V, Maier K, et al. Treatment of Crohn's disease with peroral 5 -aminosalicylic acid. Gastroenterology 1983;85:1350-3.

17. Novis BH, Korzets Z, Chen P, Bernheim J. Nephrotic syndrome after treatment with 5-aminosalicylic acid. Br Med J 1988;1:1442.

18. Riley SA, Mani V, Goodman MJ, et al. Comparison of delayed release 5 -aminosalicylic acid (mesalazine) and sulphasalazine in the treatment of mild to moderate ulcerative colitis relapse. Gut 1988;29:669-74.

19. Tremaine WJ, Schroeder KW. Oral 5-aminosalicylic acid (Asacol) tolerance versus oral sulfasalazine tolerance in patients with chronic ulcerative colitis. Gastroenterology 1986;90:1670. (Abst)

20. Dew MJ, Harris AD, Evans BK, Rhodes J. Treatment of ulcerative colitis with oral 5-aminosalicylic acid in patients unable to take sulphasalazine. Lancet 1983;i:801.

21. Campieri M, Lanfranchi GA, Brignola C, et al. 5-aminosalicylic acid as a rectal enema in ulcerative colitis patients unable to take sulphasalazine. Lancet 1984;i:403. (Lett)

22. Donald IP, Wilkinson SP. The value of 5-aminosalicylic acid in inflammatory bowel disease for patients intolerant or allergic to sulphasalazine. Postgrad Med 1985;61:1047-8.

23. Rao SS, Cann PA, Holdsworth CD. Clinical experience of the tolerance of mesalazine and olsalazine in patients intolerant to sulphasalazine. Scand J Gastroenterol 1987;22:332-6.

24. Burke DA, Manning AP, Williamson JMS, Axon ATR. Adverse reactions to sulphasalazine and 5-aminosalicylic acid in the same patients. Aliment Pharmacol Ther 1987;1:201-8.

25. Turunen U, Elomaa I, Anttila V-J, Seppalla K. Mesalazine tolerance in patients with inflammatory bowel disease and previous intolerance or allergy to sulphasalazine or sulphonamides. Scand J Gastroenterol 1987;22:798 802.

26. Habal FM, Greenberg GR. Treatment of ulcerative colitis with oral 5-aminosalicylic acid including patients with adverse reactions to sulfasalazine. Am J Gastroenterol 1988;83:15-9.

27. Dew MJ, Hughes $P$, Harries AD, et al.
Maintenance of remission in ulcerative colitis with oral preparation of 5 . aminosalicylic acid. Br Med ] 1982;285:1012.

28. Riley SA, Mani V, Goodman MJ, et al. Comparison of delayed-release 5-aminosalicylic acid (mesalazine) and sulphasalazine as maintenance treatment for patients with ulcerative colitis. Gastroenterology 1988;94:1383-9.

29. Rachmilewitz D, on behalf of an international study group. Coated mesalazine ( 5 -aminosalicylic acid) versus sulphasalazine in the treatment of active ulcerative colitis: A randomized trial. Br Med ] 1 989;298:82-6.

30. Schroeder KW, Tremaine WJ, Ilstrup DM. Coated oral 5-aminosalicylic acid therapy for mildly to moderately active ulcerative colitis. N Engl J Med 1987;317:1625-9.

31. Sachedina B, Saibil F, Cohen LB, Whitley J. Acute pancreatitis due to 5 aminosalicylate. Ann Intern Med 1989;110:490-2.

32. Deprez P, Descamps C, Fiasse R. Pancreatitis induced by 5 -aminosalicylic acid. Lancet 1989;ii:445-6.

33. Agnholt J, Sorensen HT, Rasmussen SN, Gotzsche CO, Halkier P. Cardiac hypersensitivity due to 5-aminosalicylic acid. Lancet 1989;i:1135.

34. Kristensen KS, Hoegholm A, Bohr L, Friis S. Fatal myocarditis associated with mesalazine. Lancet 1990;i:605.

35. Kutty PK, Raman KRK, Hawken K, Barrowman JA. Hair loss and 5 -aminosalicylic acid enema. Ann Intern Med 1982;97:785-6. (Lett)

36. Singleton JW, Law DH, Kelley ML Jr, Mekhjian HS, Sturdevant RAL. National Cooperative Crohn's Disease Study: Adverse reactions to study drugs. Gastroenterology 1979; 77:870. 82.

37. Sandberg-Gertzen $H$, Jarnerot $G$, Bukhave K, Lauritsen K, Rask-Madsen J. Effect of azodisal sodium and sulphasalazine on ileostomy output of fluid and $\mathrm{PGE}_{2}$ and $\mathrm{PGF}_{2}$ in subjects with a permanent ileostomy. Gut 1986;27:1306-11.

38. Goerg KJ, Wanitschke R, Breiling K, Franke M. Prostacyclin, a specific colonic stimulator of active chloride secretion. Gastroenterology 1984;86:1091.

39. Mohsen AQM, Mulvey D, Priddle JD, Parsons DS, Jewell DP. Effect of olsalazine in the jejunum of the rat. Gut 1987;28:346-52.

40. Sandberg-Gertzen H, Jarnerot G, Kraaz W. Azodisal sodium in the treatment of ulcerative colitis. Gastroenterology 1986;90:1024-30. 


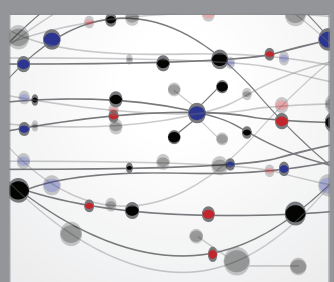

The Scientific World Journal
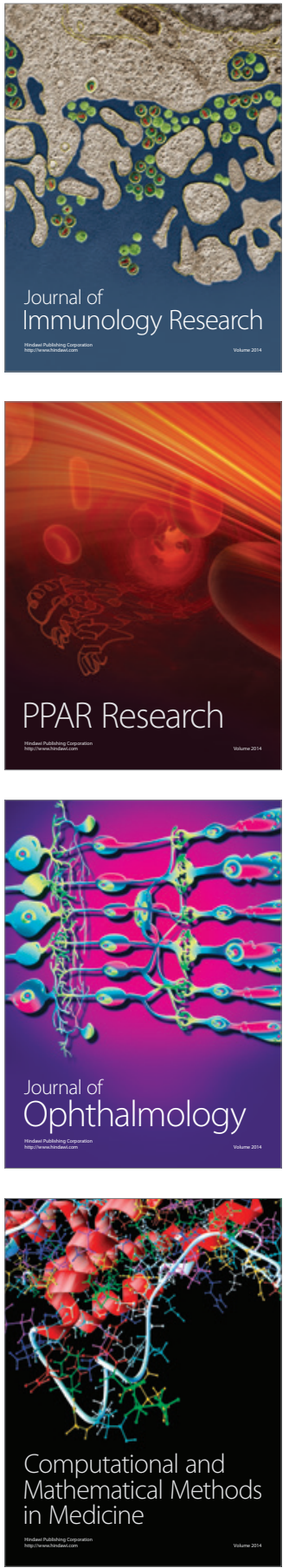

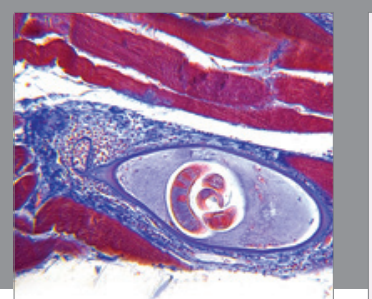

Gastroenterology Research and Practice

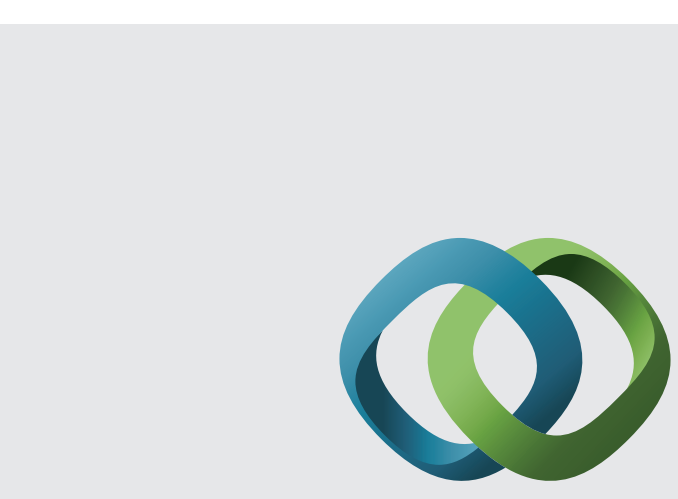

\section{Hindawi}

Submit your manuscripts at

http://www.hindawi.com
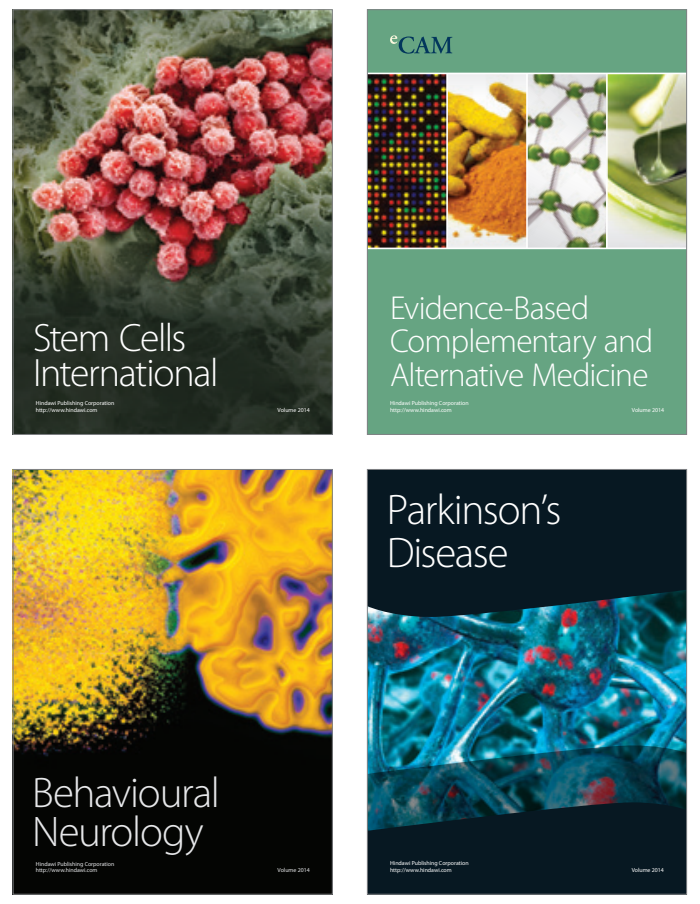
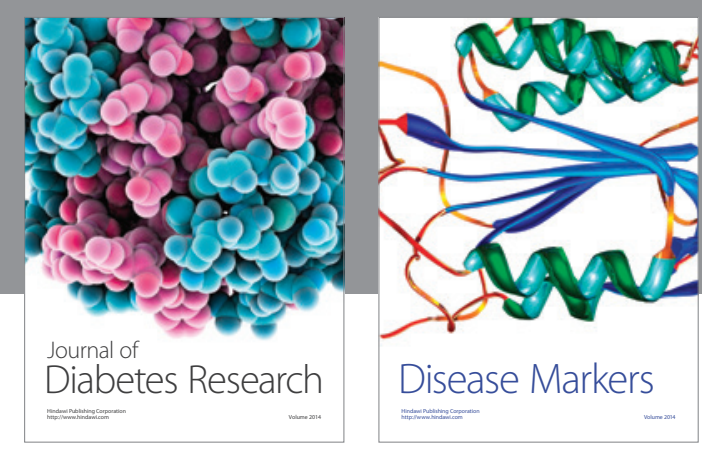

Disease Markers
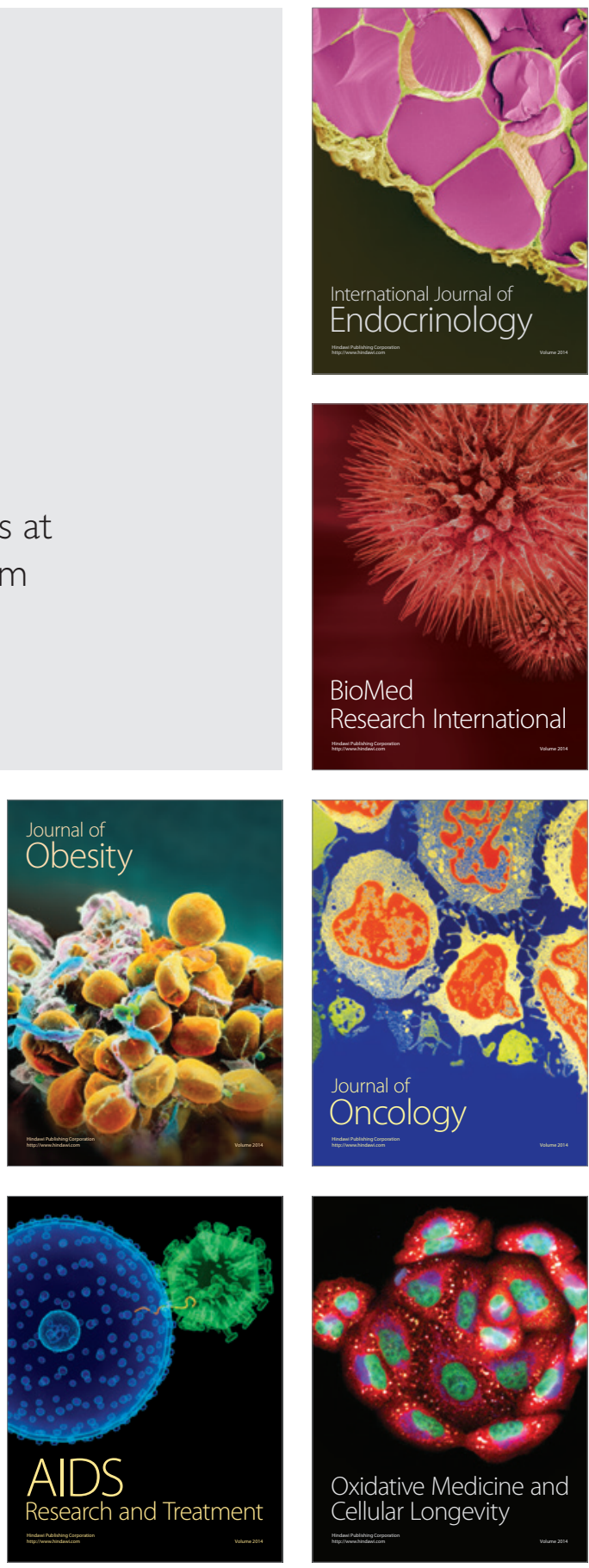